\title{
Manajemen Sarana dan Prasarana Sekolah
}

\author{
Septi Damai Yanti
}

15002048

\section{Administrasi Pendidikan}

Septydamaiyanti315@gmail.com

\begin{abstract}
Abstrak : Tulisan ini bertujuan untuk mendeskripsikan secara ringkas manajemen sarana dan prasarana di Sekolah yang terdiri dari (1) Perencanaan, (2) Penetapan, (3) Inventarisasi, (4) Pemeliharaan dan (5) Penghapusan serta peran manajemen sarana dan prasaranna pendidikan dalam pengembangan sekolah. Berbagai macam permasalahan dalam dunia pendidikan Indonesia salah satunya permasalahan sarana dan prasarana serta solusi dari permasalahan tersebut.
\end{abstract}

Kata Kunci : Manajemen, Sarana, Prasarana.

\section{A. PENDAHULUAN}

Pendidikan adalah suatu usaha sadar dan terencana untuk menjalankan dan mewujudkan proses belajar mengajar berkesinambungan dan tersusun dalam program pembelajaran yang disusun sebelum proses pembelajaran berlangsung. Bidang pendidikan merupakan salah satu andalan untuk mempersiapkan sumber daya manusia dalam bidang pendidikan dilakukan sejak dari masa pendidikan dasar, menengah dan tinggi. Peran sarana pendidikan sangat penting dalam memperlancar pelaksanaan proses pembelajaran. Satu sisi harapan yang dibebankan pada dunia pendidikan sangat banyak, tetapi di sisi lain dunia pendidikan mempunyai banyak masalah yang menghambat dalam pelaksanaan kegiatan belajar mengajar di sekolah. Salah satu masalah yang dihadapi oleh sekolah adalah masalah sarana pendidikan.

Sarana dan prasarana merupakan faktor pendukung yang sangat penting dalam dunia pendidikan selain tenaga pendidik. Pendidikan tidak akan pernah bisa berjalan dengan baik tanpa adanya sarana dan prasarana yang memadai. Sarana dan prasarana tidak akan dapat terpenuhi tanpa adanya manajemen yang dijalankan dalam lembaga pendidikan yang terkait dan dengan adanya manajemen sarana dan prasarana pendidikan akan berdaya untuk proses pembelajaran.

Dalam rangka mengatur substansi fasilitas atau sarana di sekolah di gunakan suatu pendekatan administratif tertentu yang disebut juga manajemen sarana pendidikan. Manajemen sendiri merupakan proses pendayagunaan semua sumber daya dalam rangka mencapai tujuan yang telah di tetapkan. Pendayagunaan melalui tahapan proses yang meliputi perencanaan, pengorganisasian, pengarahan, dan pengawasan. Sarana pendidikan adalah semua fasilitas yang diperlukan dalam proses belajar mengajar baik yang bergerak maupun yang tidak bergerak agar pencapaian tujuan pendidikan dapat berjalan dengan lancer, teratur, efektif, dan efisien. Jadi manajemen sarana pendidikan adalah keseluruhan proses perencanaan, pengadaan, pendayagunaan, dan pengawasan yang digunakan untuk menunjang pendidikan agar pencapaian tujuan pendidikan dapat berjalan dengan lancar, teratur, efektif, dan efisien.

\section{B. PERMASALAHAN}

Sampai saat ini 88,8 persen sekolah di indonesia mulai SD hingga SMA/SMK, belum melewati mutu standar pelayanan minimal.Pada pendidikan dasar hingga kini layanan 
pendidikan mulai dari guru, bangunan sekolah, fasilitas perpustakaan dan laboratorium, buku-buku pelajaran dan pengayaan, serta buku referensi masih minim. Pada jenjang Sekolah Dasar (SD) baru 3,29\% dari 146.904 yang masuk kategori sekolah standar nasional, $51,71 \%$ kategori standar minimal dan $44,84 \%$ dibawah standar pendidikan minimal. pada jenjang SMP $28,41 \%$ dari $34.185,44,45 \%$ berstandar minimal dan $26 \%$ tidak memenuhi standar pelayanan minimal. Hal tersebut membuktikan bahwa pendidikan di Indonesia tidak terpenuhi sarana prasarananya. Data Balitbang Depdiknas (2003) menyebutkan untuk satuan SD terdapat 146.052 lembaga yang menampung 25.918.898 siswa serta memiliki 865.258 ruang kelas. Dari seluruh ruang kelas tersebut sebanyak 364.440 atau $42,12 \%$ berkondisi baik, 299.581 atau 34,62\% mengalami kerusakan ringan dan sebanyak 201.237 atau 23,26\% mengalami kerusakan berat. Kalau kondisi MI diperhitungkan angka kerusakannya lebih tinggi karena kondisi MI lebih buruk daripada SD pada umumnya. Keadaan ini juga terjadi di SMP, MTs, SMA, MA, dan SMK meskipun dengan persentase yang tidak sama.Banyak sekali sekolah dan perguruan tinggi yang gedungnya rusak, kepemilikan dan penggunaan media belajar rendah, buku perpustakaan tidak lengkap. Sementara laboratorium tidak standar, pemakaian teknologi informasi tidak memadai dan sebagainya. Permasalahan sarana dan prasarana ini sering dijumpai pada daerah daerah yang terpencil atau pedalaman, seperti pedalaman Kalimantan. Biasanya keterbatasan sarana dan prasarana ini mulai dari gedung sekolah yang ruangannya tidak layak dipakai untuk mendapatkan suasana belajar yang nyaman dan kondusif (seperti gambar di bawah) dan hanya terdapat dua atau tiga kelas saja, tidak terdapat ruangan lain seperti perpustakaan, laboraturium sarana-sarana olahraga, sarana sarana belajar seperti buku paket yang up date serta fasilitas lainnya dan jumlah guru yang sangat terbatas. Situasi seperti itu juga terdapat di daerah perkotaan misalnya ada sekolah yang proses belajar dan pembelajarannya di lakukan di bawah jembatan dan lain lain. Banyak lagi permasalahan sarana dan prasarana sekolah di Indonesia seiring dengan perkembangan zaman dan teknologi. Misalnya adanya infocus di tiap kelas, jaringan internet atau wirless di sekolah dll.

\section{C.KAJIAN TEORITIS DAN PEMBAHASAN}

Pengelolaan merupakan terjemahan dari kata manajemen yang berasal darikata "management", istilah Inggris tersebut lalu dindonesiakan menjadi "Manajemen". Menurut (Mulyasa,2002:50) manajemen sarana dan prasarana pendidikan bertugas untuk mengatur dan menjaga sarana dan prasarana pendidikan agar dapat memberikan kontribusi secara optimal dan berarti pada jalannya proses pendidikan. Dan menurut (Syahril, 2004:9) pengelolaan sarana prasarana adalah proses pengurusan, penataan dan pengaturan kegiatan secara sistematis agar berfungsi menurut fungsinya masing-masing dalam rangka mencapai tujuan yang ditetapkan.

Berdasarkan pendapat diatas yang dimaksud dengan pengelolaan sarana pendidikan adalah proses atau cara melaksanakan pengadaan, pemeliharaan serta pengawasan sarana dan prasarana untuk mencapai suatu tujuan yang telah ditetapkan. Intinya pengelolaan sarana prasarana merupakan proses pengurusan.

1. Perencanaan Sarana dan Prasarana Pendidikan dalam Proses Pembelajaran

Perencanaan sarana dan prasarana pendidikan pertama melalui analisis kebutuhan dilakukan dengan menganalisis dan mengevaluasi sarana dan prasarana apa saja yang diperlukan untuk mendukung 
proses pembelajaran di dalam kelas maupun di luar kelas. Hal tersebut secara garis besar selaras dengan teori yang dikemukakan oleh Kompri (2014) intinya menyatakan bahwa analisis kebutuhan sarana dan prasarana pendidikan dilakukan pada proses perencanaan dan analisis tersebut menyangkut pada kebutuhan pada sarana dan prasarana dalam pembelajaran. Kegiatana analisis sarana dan prasarana pendidikan melibatkan guru kelas maupun guru mata pelajaran, akan tetapi peranan guru kelas dalam menganalisis kebutuhan lebih besar tanggung jawabnya daripada guru mata pelajaran. Dengan menganalisis sarana dan prasarana pendidikan menjadi satu langkah yang penting untuk dilakukan disetiap lembaga pendidikan. Dalam analisis terdapat satu langkah yang sangat penting yaitu evaluasi. Evaluasi mempunyai tujuan untuk mengetahui kualitas dan kuantitas sarana dan prasarana pendidikan.

Dengan demikian proses analisis dan evaluasi untuk menentukan pengadaan sarana dan prasarana sangat diperhatikan dengan baik. Dimana kedua hal tersebut merupakan penunjang proses pembelajaran. Perencanaan sarana dan prasarana pendidikan yang kedua adalah analisis pembiayaan dilakukan untuk memenuhi kebutuhan pembelian sarana dan prasarana dan untuk meminimalisir penggunaan dana yang tidak tepat sasaran. Hal tersebut senada dengan teori yang diungkapkan oleh Gunawan dan Benty (2017) intinya menyatakan bahwa dalam proses perencanaan sarana dan prasarana pendidikan harus memperhatikan estimasi biaya yang tersedia di lembaga sekolah. Selain senada dengan teori yang diungkapkan oleh Gunawan dan Benty temuan diatas juga didukung dengan temuan Idris (2013) intinya menyatakan bahwa penyedian sarana dan prasarana pendidikan secara umum melalui dana dari pemerintah. Ketersediaan dana pendidikan sangatlah penting dalam setiap lembaga terutama lembaga pendidikan. Dana yang tersedia pada lembaga pendidikan diperguankan untuk memenuhi kebutuhan sekolah salah satunya dalam pemenuhan sarana dan prasarana pendidikan. Dana yang diberikan pemerintah tidak mampu untuk memenuhi kebutuhan-kebutuhan yang secara keseluruhan. Dengan demikian analisis penggunaan dana pendidikan sangat diperlukan sehingga tidak menimbulkan permasalah pada pendanaan lembaga sekolah. Analisis pembiayaan dilakukan untuk mengendalikan dana yang tersedia untuk penyediaan sarana dan prasarana yang diprioritaskan sekolah seperti pembelian buku-buku, alat tulis kantor (ATK), dan alat peraga. Perencanaan sarana dan prasarana pendidikan yang ketiga adalah analisis prioritas merupakan pemilihan dari usulanusalan guru dalam perencanaan sarana dan prasarana pendidikan yang dibutuhkan sekolah dan peserta didik dan mengacu pada dana pendidikan yang tersedia. Hal tersebut sesuai dengan teori yang dikemukakan oleh Gunawan dan Benty (2017) yang menyatakan bahwa menetapkan prioritas sarana dan prasarana dalam perencanaan merupakan hal penting yang perlu diperhatikan sebelum pengadaan itu direalisasikan. Analisis prioritas sarana dan prasarana selain untuk memenuhi kebutuhan sekolah dalam kaitannya dengan proses pembelajaran analisis prioritas juga mempunyai tujuan lain yaitu untuk mengurangi pengeluaran pembiayaan dalam penyedian sarana dan prasarana yang masih mempunyai daya guna. Sarana dan prasarana yang diprioritaskan semuanya mengacu pada kegunaan pembelajaran di dalam kelas.

2. Pengadaan Sarana dan Prasarana Pendidikan dalam Proses Pembelajaran

Pengadaan sarana dan prasarana pendidikan yang pertama adalah penetapan, penetapan dilakukan bersama-sama dengan semua pihak sekolah mengacu pada kebutuhan yang sangat penting untuk mendukung proses pembelajaran. Hal tersebut didukung oleh Ihuoma (2008) intinya menyatakan bahwa dalam penetapan sarana dan prasarana mengacu pada suatu tujuan diadakannya sarana dan prasarana 
tersebut. Tujuan utama dalam penetapan untuk memenuhi kebutuhan proses pembelajaran di dalam kelas. Dengan demikian pengadaan sarana dan prasarana pendidikan dilakukan oleh pimpinan sekolah yang berlandaskan pada kesepakatan bersama dan dengan melihat kebutuhan kebutuhan yang diperlukan sekolah. Pengadaan sarana dan prasarana pendidikan yang kedua adalah sumber pengadaan, sumber pengadaan melalui reparasi barangbarang yang rusak, pembelian barang baru menggunakan dana dari pemerintah dan sumbangan masyarakat, peminjaman dari pihak swasta dan penukaran barang baru dengan barang yang sudah rusak.

Temuan tersebut didukung dengan temuan Taylor (2011) intinya menyatakan bahwa dalam hal pengadaan sarana dan prasrana pendidikan menggunakan dana dari pihak pemerintah dan pihak swasta yang berkaitan langsung dengan lembaga pendidikan. Temuan di atas selaras dengan teori yang diungkapkan oleh Gunawan dan Benty (2017) intinya mengungkapkan bahwa sumber pengadaan sarana dan prasarana dapat melalui pembelian, pembuatan sendiri, penerimaan hibah atau pinjaman dari pihak swasta, penyewaan, dan pinjaman-pinjaman dari lembaga yang terkait dengan sekolah. Selain selaras dengan temuan dari Gronberg dan teori yang dikemukakan oleh Gunawan dan Benty temuan di atas juga selaras dengan Kompri (2014) intinya mengungkapkan bahwa pengadaan sarana dan prasarana pendidikan melalui beberapa cara yaitu: pembelian, pembuatan secara mandiri, penyewaan, dan penerimaan hibah atau sumbangan dari pihak lain. Dengan demikian temuan peneliti mengenai pengadaan sarana dan prasarana di SD Negeri Ngrukeman Tamantirto selasar dengan temuan yang pernah dilakukan peneliti terdahulu dan sesuai dengan teoriteori yang diungkapkan di atas. Sehingga bisa disimpulka sementara bahwa pengadaan sarana dan prasarana pendidikan melalui beberapa cara seperti: pembelian baru, pembuatan sendiri, penyewaan, penerimaan hibah, dan reparasi barang- barang yang ada. Pengadaan sarana dan prasarana pendidikan yang ketiga adalah kualitas sarana dan prasarana yang ditetapkan seperti kegunaaan jangka waktu yang lama untuk alat peraga, untuk buku berupa tulisan, jumlah halaman, gambar sudah jelas dan isi buku tidak ada konten yang tidak baik. Hal tersebut senada dengan teori yang diungkapkan oleh Gunawan dan Benty (2017) intinya menyatakan bahwa pengadaan sarana dan prasarana pendidikan harus akuntabel yang berarti pengadaaan tersebut harus mencapai sasaran baik fisik, keuangan maupun manfaat bagi kelancaran pembelajaran.Dengan memperhatikan kualitas dari setiap sarana dan prasarana pendidikan akan memberikan suatu hal yang berdaya guna dengan maksimal dan efektif. Salah satu contoh kualitas yang harus dalam keadaan yang baik adalah pada alat-alat peraga pembelajaran, dengan kualitas yang baik maka alat tersebut dapat digunakan oleh siswa dengan maksimal. Pengadaan sarana dan prasarana pendidikan yang keempat adalah fungsi sarana dan prasarana, dapat dilihat dari fungsinya untuk proses pendukung pembelajaran yang dilakukan siswa dan guru didalam kelas. Hal tersebut didukung dengan pernyataan yang diungkapkan oleh Oluwole (2012) intinya menyatakan bahwa pengadaan sarana dan prasarana pendidikan ditujukan untuk memenuhi kebutuhan sekolah. Pernyataan yang sesuai denga temuan di atas kemudian sesuai dengan teori yang diungkapkan oleh Gunawan dan Benty (2017) intinya menyatakan bahwa fungsi sarana dan prasarana harus efektif dalam artian pengadaan sarana dan prasarana pendidikan harus sesuai dengan kebutuhan yang telah ditetapkan dan dapat memberikan manfaat yang sebesar-besarnya bagi lembaga pendidikan secara umum dan secara khusus kepada siswa. Selain itu teori yang diungkapkan oleh Gunawan dan Benty selaras dengan temuan Uko (2015) menyatakan bahwa fasilitas sekolah memiliki fungsi yang sangat penting yaitu untuk memberikan dukungan kepada siswa untuk dapat berprestasi dalam bidang 
akademik. Langkah yang ditempuh dalam pengadaan sarana dan prasarana yang akan bisa memberikan manfaat yang positif kepada guru dan peseta didik dalam proses kegiatan pembelajaran dengan tujuan untuk sarana mencapai prestasi akademik siswa.

3. Penginventarisasi Sarana dan Prasarana Pendidikan dalam Proses Pembelajaran

Penginventarisasi sarana dan prasarana pendidikan yang pertama adalah untu pengendalian sarana dan prasarana melalui pemberian kode barang, nama barang, sumber barang/penerbit (buku), volume/jumlah barang, tanggal perolehan/pembelian barang, mutasi/perubahan, sumber dana dan keterangan barang. Hal tersebut sesuai dengan teori yang dikemukakan oleh Kompri (2014) intinya menyatakan bahwa dalam kegiatan inventarisasi yang digunakan untuk mengendalikan sarana dan prasarana adalah dengan melakukan pencatatan sarana dan prasarana dan melakukan pembuatan kode.Melalui pencatatan yang rincin terhadap sarana dan prasarana pendidikan akan memberikan kemudahan bagi penanggung jawab sarana dan prasarana dalam mengendalikannya sesuai dengan penggunaan dan perawatan barang-barang tersebut. Penginventarisasi sarana dan prasarana pendidikan yang kedua adalah untuk pengawasan sarana dan prasarana, pengawasan dilakukan dengan mengecek buku inventarisasi sarana dan prasaran pendidikan yang didalam buku tersebut terdapat barang-barang yang telah diadakan. Hal tersebut didukung dengan teori yang diungkapkan oleh Gunawan dan Benty (2017) intinya menyatakan bahwa setelah pencatatan dan pemberian kode pada setiap sarana dan prasarana yang diadakan memiliki tujuan agar semua pihak sekolah mudah mengenal kembali perlengkapan di sekolah baik ditinjau dari segi kepemilikan sampai pada penanggungjawab dan pengawasan. Pengawasan sarana dan prasarana menjadi tanggung jawab sekolah dimana tidak semua barang yang ada milik sekolah melaikan milik pemerintah. Dengan adanya pengawasan yang baik maka resiko akan terjadi hal-hal yang tidak diinginkan akan dapat diminimalisir oleh pihak sekolah

4. Pemeliharaan Sarana dan Prasarana Pendidikan dalam Proses Pembelajaran

Pemeliharaan sarana dan prasarana pendidikan yang pertama adalah pada pemeliharaan sehari-hari dilakukan oleh setiap guru dan semua siswa, pemeliharaan yang dilakukan seperti membersihkan ruang kelas, menyimpan alat-alat pembelajaran setelah digunakan, dan perawatan bukubuku pelajaran. Hal tersebut didukung oleh Gonzales (2011) intinya menyatakan bahwa dengan adanya perawatan yang dilakukan setiap hari sarana dan prasarana pendidikan dapat terpelihara dengan baik dan mampu mendukung proses pembelajaran. Selanjutnya temuan di atas didukung teori Gunawan dan Benty (2017) yang pada intinya menyatakan bahwa pemeliharaan setiap hari untuk mengkondisikan sarana dan prasarana dalam keadaan siap pakai dan dapat mengurangi resiko kerusakan. Dengan pemeliharaan harus dilakukan oleh seluruh warga sekolah untuk mempersiapan sarana dan prasarana pembelajaran yang dapat digunakan setiap saat dalam kondisi yang baik dan siap digunakan guru dan peserta didik. Sarana dan prasarana yang sudah terkodisikan dengan baik akan dapat mendukung proses pembelajaran secara baik. Pemeliharaan sarana dan prasarana pendidikan yang kedua adalah Pemeliharaan berkala mencakup pada pemeliharaan gedung sekolah pengecatan tembok, penggantian plafon yang rusak, perbaikan kursi dan meja, LCD, dan komputer.Hal tersebut selaras dengan teori yang diungkapkan oleh Gunawan dan Benty (2017) intinya dalam pemeliharaan berkala mencakup sarana dan prasarana yang digunakan dalam jangka yang panjang, pemeliharaan yang dilakukan seperti penggantian spare-part, penggantian dengan spesifikasi terbaru. Dengan demikian pemeliharaan berkala merupakan salah satu langkah yang dilakukan untuk meminimalisir pembeliaan baru yang 
membutuhkan dana yang lebih besar. Dengan dasar seperti itu maka pemeliharaan berkala dilakukan untuk merawat prasarana sekolah supaya prasarana sekolah bisa terkontrol dengan baik.

5. Penghapusan Sarana dan Prasarana Pendidikan dalam Proses Pembelajaran

Penghapusan sarana dan prasarana pendidikan yang pertama melalui prosedur penghapusan, prosedur yang ada seperti pemberian blangko penghapusan kepada setiap sekolah, kemudian sekolah mencatat barang-barang apa saja yang akan dihapus, selanjutnya setelah pencatatan barang dilaporkan kepada dinas pendidikan maka peninjauan lapangan dilakukan oleh BPK. Hal tersebut senada dengan teori Gunawan dan Benty (2017) yang intinya menyatakan bahwa dalam prosedur penghapusan harus memperhatikan langkah langkah seperti: pembentukan tim, mengidentifikasi jenisjenis barang yang akan dihapus, mencatat sarana dan prasarana yang akan dihapus, dan persetujuan dari pihak sekolah. Dengan demikian penghapusan sarana dan prasarana pendidikan harus melalui prosedur penghapusan yang telah ditetapkan pemerintah kota dan dengan memperhatikan langkah langkah penghapusan sarana dan prasarana pendidikan dengan tujuan penghematan anggaran dan pembebasan ruang pendidkan. Penghapusan sarana dan prasarana pendidikan yang kedua adalah untuk meringankan beban kerja dan pencegahan keborosan, dengan penghapusan sarana dan prasarana yang tidak digunakan secara efektif dapat mengurangi beban kerja dan pencegahan pemborosan dana dalam pemeriharaan atau perawatan sarana dan prasarana yang sudah tidak mampu digunakan secara maksimal. Temuan tersebut sesuai dengan teori Arifin dan Widyaiswara (Kompri, 2014: 260) yang intinya menyatakan bahwa penghapusan sarana dan prasarana pendidikan dilakukan bertujuan untuk mengurangi pembiayaan perawatan dan membebaskan lembaga dari tanggung jawab pemeliharaan sarana dan prasarana. Barang-barang yang sudah tidak mampu digunakan secara maksimal merupakan alasan dilakukannya penghapusan, temuan tersebut senada dengan teori Kompri (2014) menyatakan bahwa ada beberapa pertimbangan yang dilakukan untuk penghapusan yaitu: dalam keadaan rusak, perbaikan memerlukan pembiayaan yang relatif besar, dan tidak sesuai dengan kebutuhan sekolah. Dengan demikian penghapusan dilakukan untuk sarana yang sudah tidak dapat digunakan dengan maksimal. Selain untuk penghematan anggaran dan pembebasan ruang pendidikan, penghapusan juga memiliki tujuan lain yaitu meringankan beban kerja tenaga pendidik dan kependidikan di sekolah.

6. Peran manajemen sarana dan prasarana dalam pengembangan sekolah

Peran manajemen sarana prasarana pendidikan dalam pengembangan sekolah sangat berpengaruh sekali, karena dengan pengelolaan sarana dan prasarana yang baik akan meningkatkan kualitas dan kuantitas sekolah dengan berbagai prestasi yang diraih, sehingga memikat orang tua peserta didik untuk menyekolahkan anaknya. Menurut Darmawan (2014: 9-10) Standar sarana prasarana Sekolah merupakan bagian dari kebijakan untuk memperbaiki dan meningkatkan layanan dasar dan kualitas dari penyelenggaraan pendidikan. Sedangkan kegiatan perencanaan sarana dan Prasarana sangat diperlukan baik untuk jangka pendek maupun jangka panjang. Hal ini penting dilakukan secara rigit dengan maksud agar terjadi suatu kesesuaian antara kebutuhan akan sarana dan prasarana, ketersediaan dana, dan kemanfaatan barang tersebut sehingga menunjukkan adanya kepastian arah dan tujuan. Kelengkapan sarana prasarana dan pengelolaan sarana prasarana yang baik akan mempermudah sekolah dalam mengembangkan sekolahnya melalui prestasi yang di capai sekolah ataupun peserta didik (akademik ataupun non-akademik). Jika manajemen sarana dan prasarana yang dilaksanakan bisa berjalan dengan lancar dan baik maka kegiatan 
proses pembelajarannya pun tidak akan terganggu, sebaliknya jika suatu sekolah tidak mampu memanajemen sarana dan prasarananya dengan baik maka proses pembelajarannya pun akan terganggu sehingga tujuan pendidikan akan sulit tercapai.

\section{KESIMPULAN DAN SARAN}

1. Manajemen sarana dan prasarana sekolah meliputi beberapa tahap diantaranya : (1)Perencanaan Sarana dan Prasarana Pendidikan dalam Proses Pembelajaran (2) Pengadaan Sarana dan Prasarana (3) Penginventarisasi Sarana dan Prasarana Pendidikan dalam Proses Pembelajaran (4). Pemeliharaan Sarana dan Prasarana Pendidikan dalam Proses Pembelajaran (5). Penghapusan Sarana dan Prasarana Pendidikan dalam Proses Pembelajaran.

Pertama, perencanaan sarana dan prasarana yang dilakukan oleh kepala sekolah sesuai dengan ketentuan. Setiap tahun kepala sekolah menampung semua usulan rencana kebutuhan. Berdasarkan usulan tersebut kemudian disusun rencana kebutuhan sekolah di awal tahun pelajaran yang kemudian disesuakan dengan anggarana atau dana, membuat skala prioritas dan penetapan rencana pengadaan akhir.

Kedua, pengadaan sarana prasarana dilakukan dengan cara; (1) drooping dari pemerintah; (2) membeli, (3) sumbangan dari wali murid, (4) membuat sendiri.

Ketiga, inventarisasi sarana dan prasarana sekolah sudah dilakukan dengan cara mencatat dalam buku inventaris barang. Pencatatan dilakukan terhadap semua barang masuk.

Keempat, pendistribusian sarana dan prasarana dilakukan dengan cara: (1) langsung kepada guru setelah di catat di buku inventaris; (2) tidak langsung, yaitu dengan cara disimpan dahulu ketika akan menggunakan baru diambil dan setelah dipakai disimpan kembali ketempat semula.
Kelima, pemeliharaan sarana dan prasarana sekolah dilakukan dengan cara yaitu; (a) berkala yaitu dengan pemeliharaan dilakukan setiap hari, selalu dijaga kebersihannya, digunakan saat membutuhkan dan disimpan di tempatnya setelah digunakan, selalu melakukan pengecekan terhadap sarana dan prasarana di sekolah untuk memastikan kelayakan sarana dan prasarana tersebut; (b) insidental yaitu melakukan pemeriksaan terhadap sarana dan prasarana sewaktu-waktu, jika ada yang rusak kemudian diperbaiki, sarana prasarana yang tidak dapat diperbaiki akan disimpan.

Keenam, penghapusan sarana dan prasarana dilakukan terhadap barang yang rusak berat dengan dilakukan penyimpanan dalam lemari dan gudang.

Ketujuh, pengawasan dan pertanggungjawaban (pelaporan) sarana dan prasarana dilakukan oleh kepala sekolah dan dilakukan setiap setahun sekali ketika tahun ajaran baru.

1. Solusi dari permasalahan dalam manajemen sarana dan prasarana :

Ada beberapa hal yang dapat kita lakukan dalam memperbaiki anomali-anomali pendidikan ini antaralain:

- Terorganisirnya koordinasi antara pemerintah pusat dengan pemerintah daerah, bahkan hingga daerah terpencil sekalipun sehingga tidak terputusnya komunikasi antara pemerintah pusat dengan daerah

- Dengan adanya koordinasi pemerintah pusat dengan pemerintah daerah maka selanjutnya kita dapat meningkatkan Sarana dan Prasarana Pendidikan

- Hendaknya pemerintah melengkapi kekuranagan sarana dan prasarana di sekolah dan kepada pihak sekolah hendaknya mampu menjaga sarana dan prasarana dengan baik. 


\section{DAFTAR RUJUKAN}

Arifin .M dan Barnawi. (2017). Manajemen Sarana dan Prasarana Sekolah. Manajer Pendidikan.

Barnawi, \& Arifin, M. (2012). Manajemen sarana dan prasarana sekolah, (171011500095).

Jahar Ahlian Prestysa. (2017). لا IStandarisi
Sarana dan Prasarana dalam Pengembangan Sekolah di SDIT Muhammadiyah Al-Kautasar, 15.

Retrieved from http://www.albayan.ae Nasrudin dan Maryadi. (1907). Manajemen Sarana dan Prasana Pendidikan dalam Pembelajaran di SD, 13(2), 15-23. 